\title{
Epidemiological Study on Bronchial Asthma at Shaheed Suhrawardy Medical College Hospital, Dhaka
}

\author{
Barua $\mathrm{UK}^{1}$, Saha $\mathrm{SK}^{2}$, Ghosh DK ${ }^{3}$, Ruble $\mathrm{MMK}^{4}$
}

\begin{abstract}
Background: In Bangladesh more than 100 million people are suffering from cough and shortness of breath. Still people are getting unplanned treatment and taking unscientific, indigenous and sometimes harmful products to get relief. Objective: The present study was conducted to estimate the prevalence of different types of bronchial asthma in Shaheed Suhrawardy Medical College Hospital. Methodology: One hundred patients from respiratory medicine out patient department were included in this study using a well designed questionnaire, clinical examination by physician which was carried out from January, 2012 to June, 2012. The key questions were related to the type of asthma, family history, presence of atopic dermatitis and diabetes, information on smoking and alcoholic habits, domestic cooking fuel used, dwelling area, age, religion, socioeconomic status and age of onset of disease. Result: Out of 100 subjects surveyed, 42 were females and 58 were males. The type of asthma is distributed as cough-variant-asthma (8\%), intermittent asthma $(52 \%)$, persistent asthma (16\%), seasonal asthma (22\%) and occupational asthma (2\%). Regarding family history, $26 \%$ showed genetic predisposition irrespective of sex. Among asthmatics, $6 \%$ were having atopic dermatitis. Forty percent were smokers, $5 \%$ were alcoholics and $28 \%$ were with diabetics. Advancing age, usual residence in urban area and lower socio-economic status were associated with significantly higher odds of having asthma. Conclusion: It showed that cough- variant-asthma, diabetes and smoking habit increase the incidence of asthma attacks. [J Shaheed Suhrawardy Med Coll, 2013;5(2):77-80]
\end{abstract}

Keywords: Bronchial asthma, epidemiological study, respiratory distress, cough

Received: August 2013; Revised: October 2013; Accepted: November 2013

\section{Introduction}

Asthma is a global health problem affecting about 300 million people ${ }^{1}$. It is estimated that there may be an additional 100 million people with asthma by $2025^{2}$. Asthma accounts for about $^{1}$ in every 250 deaths worldwide ${ }^{3}$, although modern management, which obviously includes patient education, can prevent $80 \%$ of such death ${ }^{4}$. The economic cost of asthma is considerable both in terms of direct - medical costs such as hospital admission, and cost of pharmaceuticals and indirect medical costs such as loss of work-time and premature death $^{5}$.
Bronchial Asthma is a chronic inflammatory disorder of the airways associated with airway hyperresponsiveness that leads to recurrent episodes of wheezing, breathlessness, chest tightness and coughing particularly at night or in the early morning ${ }^{3}$. These episodes are usually associated with widespread and variable airflow obstruction which is often reversible either spontaneously or with treatment ${ }^{1}$. There has been an increase in the healthcare burden due to asthma globally. The prevalence and mortality from asthma have shown an upward trend during an era when quality medications are easily available for asthma ${ }^{2}$. While this increase in the prevalence of

1. Dr. Uttam Kumar Barua, Professor \& Head, Department of Respiratory Medicine, Shaheed Suhrawardy Medical College, Dhaka

2. Dr. Santosh Kumar Saha, Junior Consultant, Department of Pediatrics, National Center for Control of Rheumatic Fever \& Heart Disease, Dhaka

3. Dr. Dilip Kumar Ghosh, Assistant Professor, Department of Gastroenterology, Shaheed Suhrawardy Medical College, Dhaka

4. Dr. Md. Mesbahul Karim Ruble, Assistant Professor, Department of Respiratory Medicine, Shaheed Suhrawardy Medical College, Dhaka

\section{Correspondence}

Dr. Uttam Kumar Barua, Professor \& Head, Department of Respiratory Medicine, Shaheed Suhrawardy Medical College, Sher-E-Bangla Nagar, Dhaka-1207,Bangladesh; Email: dr_uk_barua@yahoo.com; Cell: 01819402358

Conflict of interest: No conflict of interest

Financial Support: None

Contributions by authors: UKB \& SKS contributed from preparation of protocol to write up of the article; DKG \& MMKR revised the manuscript 
asthma is rather global in nature, a difference does exist between the epidemiology, clinical spectrum and the management practices in Bangladesh and those in west $\mathrm{t}^{3}$. The risks for developing asthma depend on a complex interaction of hereditary and environmental factors. Risk factors are genetic predisposition family history of atopy or asthma perinatal factors low birth weight, prematurity exposure to allergens; infections respiratory infections, especially those caused by respiratory syncytial virus environmental air pollution; tobacco smoke; diet and obesity $^{4}$. Some of the differences are attributable to differences in the environmental exposures and health care infrastructure in Bangladesh while others could be truly genetic or ethnic in origin. Exposure to indoor pollutants represents a potentially modifiable cause of allergic sensitization and asthma. So, it becomes to establish which environmental factors might influence the development of asthma in predisposed individuals. Primary prevention includes creation of a productive environmental situation, leading healthy life-style, elimination of environmental factors or pollution ${ }^{6}$. There are only a few studies from Bangladesh on epidemiology of asthma. According to first national asthma prevalence study (NAPS) in Bangladesh about 7 million people (5.2\%) suffering from current asthma, more than $90 \%$ of whom do not take modern treatment ${ }^{7}$. In a study done by Aggarwal et $\mathrm{al}^{8}$ the prevalence of asthma was found to vary from $4.3 \%-6.9 \%$ in the Indian subcontinent population. Asthma continues to place a heavy burden on patients and their families as well as the health-care system. This is the time to establish well-designed clinical trials to allow rapid evaluation of new and existing therapeutic approaches for asthma.

\section{Methodology}

The present study was a cross sectional descriptive study and was carried out in one hundred asthma patients in the Department of Respiratory Medicine at Shaheed Suhrawardy Medical College Hospital, Dhaka for a period of 6 months from January 20012 to June 2012. The patients who visit this hospital are mostly from low socioeconomic status. Consent was obtained from the participating subjects after the purpose of the study was explained to them. The questionnaire was designed after at collecting information of asthma cases regarding demographical and environmental exposure factors. Patient data were obtained by interviewing the patient. The data of the patient included religion, age, gender, type of cooking fuel, dwelling area, occupation and income, education, dietary habit, family history of atopic dermatitis, smoking and alcoholic habit $\&$ diabetes. The data were analyzed by using SPSS Version 16.0.

\section{Results}

A total of 100 asthma patients were evaluated by using a questionnaire. The demographic profiles of the study group were recorded (table 1).
Table 1: Demographic profile of the subjects

\begin{tabular}{|c|c|c|}
\hline $\begin{array}{l}\text { Demographic } \\
\text { profile }\end{array}$ & Frequency & Percentage \\
\hline $\begin{array}{l}\text { Religion } \\
\text { - } \quad \text { Muslims } \\
\text { - Hindus } \\
\text { - Christians } \\
\text { Total }\end{array}$ & $\begin{array}{c}91 \\
8 \\
1 \\
100\end{array}$ & $\begin{array}{c}91.0 \\
8.0 \\
1.0 \\
100.0\end{array}$ \\
\hline 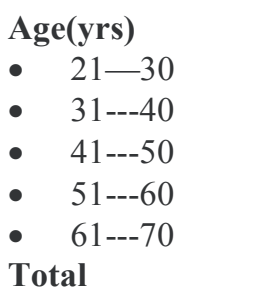 & $\begin{array}{c}10 \\
14 \\
32 \\
26 \\
18 \\
100\end{array}$ & $\begin{array}{c}10.0 \\
14.0 \\
32.0 \\
26.0 \\
18.0 \\
100.0\end{array}$ \\
\hline $\begin{array}{l}\text { Sex } \\
-\quad \text { Male } \\
\text { - Female } \\
\text { Total }\end{array}$ & $\begin{array}{c}58 \\
42 \\
100\end{array}$ & $\begin{array}{c}58.0 \\
42.0 \\
100.0\end{array}$ \\
\hline $\begin{array}{l}\text { Type of fuel } \\
\text { - } \quad \text { Gas } \\
\text { - } \quad \text { Bio-fuel } \\
\text { - } \quad \text { solid fuel } \\
\text { Total }\end{array}$ & $\begin{array}{c}65 \\
05 \\
30 \\
100.0\end{array}$ & $\begin{array}{c}65.0 \\
5.0 \\
30.0 \\
100.0\end{array}$ \\
\hline $\begin{array}{l}\text { Area of Residence } \\
\text { - Urban } \\
\text { - Urban slum } \\
\text { - Rural } \\
\text { Total }\end{array}$ & $\begin{array}{c}46 \\
26 \\
28 \\
100\end{array}$ & $\begin{array}{c}46.0 \\
26.0 \\
28.0 \\
100.0\end{array}$ \\
\hline $\begin{array}{ll}\text { Occupation } \\
\text { - } \quad \text { Labor } \\
\text { - } \quad \text { Student } \\
\text { - } \quad \text { Service } \\
\text { - } \quad \text { Housewife } \\
\text { - } \quad \text { Business } \\
\text { Total }\end{array}$ & $\begin{array}{c}32 \\
12 \\
17 \\
25 \\
14 \\
100\end{array}$ & $\begin{array}{c}32.0 \\
12.0 \\
17.0 \\
25.0 \\
14.0 \\
100.0\end{array}$ \\
\hline $\begin{array}{l}\text { Education } \\
\text { - Literates } \\
\text { - Illiterates } \\
\text { Total }\end{array}$ & $\begin{array}{c}66 \\
34 \\
100\end{array}$ & $\begin{array}{c}66.0 \\
34.0 \\
100.0\end{array}$ \\
\hline
\end{tabular}

Majority of patients (91\%) were Muslims whereas Christians and Hindus were $1 \%$ and $8 \%$ respectively. More number of subjects (58\%) were found to be between the age group of 31-60 years. Males (58\%) out-numbered females (42\%). Majority of the study group (65\%) utilized LPG cooking gas. Urban people (72\%) were found to be more affected than rural people (28\%). The number of literates (66\%) was more than illiterates (34\%). Majority of people belonged to low income category $(72 \%)$. Family history of bronchial asthma was observed in $26 \%$ of patients while $74 \%$ did not have any family history. Only $6 \%$ patient have family history of atopic dermatitis A positive association of bronchial asthma was found with family history. 
Table 2: Family History of Asthma and Atopic Dermatitis

\begin{tabular}{lcc}
\hline $\begin{array}{l}\text { Family history } \\
\text { Asthma }\end{array}$ & Frequency & Percentage \\
\hline - Yes & 26 & 26.0 \\
- No & 74 & 74.0 \\
Total & 100 & 100.0 \\
\hline Atopic dermatitis & Frequency & Percentage \\
\hline - Yes & 06 & 6.0 \\
- No & 94 & 94.0 \\
Total & 100 & 100.0 \\
\hline
\end{tabular}

Table 3: Distribution of Type of Asthma and Physical Findings

\begin{tabular}{lcc}
\hline Variables & Frequency & Percentage \\
\hline Types of asthma & 52 & 52.0 \\
- Intermittent & 16 & 16.0 \\
- Persistent & 8 & 8.0 \\
- Cough variant & 22 & 22.0 \\
- Seasonal & 2 & 2.0 \\
- Occupational & & \\
Presence of atopic dermatitis & 12 & 12.0 \\
- Yes & 88 & 88.0 \\
- No & & \\
Physical conditions & 92 & 92.0 \\
- Wheezing & 100 & 100.0 \\
- Coughing & 58 & 58.0 \\
- Shortness of breath & 76 & 76.0 \\
- Nasal problem & & \\
\hline
\end{tabular}

Majority (52\%) of the subjects had intermittent asthma. Among the other asthmatics, 16\% were had persistent asthma and $22 \%$ had seasonal $8 \%$ had cough variant asthma whereas very few had occupational asthma (2\%). Twelve ${ }^{12}$ percent patients had atopic dermatitis. Regarding physical condition of asthmatics, all the four symptoms occurred in almost all the asthmatics with different frequencies (table 3).

Table 4: Smokers, Alcoholics and Diabetics in Asthma Patients

\begin{tabular}{lccc}
\hline Age group (Yrs) & Smokers & Alcoholics & Diabetes \\
\hline $21--30$ & 05 & 01 & 0 \\
$31--40$ & 11 & 02 & 02 \\
$41--50$ & 13 & 02 & 07 \\
$51--60$ & 08 & 0 & 12 \\
$61-70$ & 03 & 0 & 07 \\
Total & $\mathbf{4 0 ( 4 0 \% )}$ & $\mathbf{5 ( 5 \% )}$ & $\mathbf{2 8 ( 2 8 \% )}$ \\
\hline
\end{tabular}

Frequency of smokers and alcoholics in asthma patients were $40 \%$ and $5 \%$ respectively. Female-smokers and alcoholics were not found. The asthamatics suffering from diabetes was $28 \%$.

\section{Discussion}

Asthma has been recognized as a disease which results in increased morbidity and mortality ${ }^{1}$. The magnitude of the problem of asthma has not been defined with certainty, despite several epidemiological studies conducted throughout the world ${ }^{3-7}$. Indeed, studies on the prevalence of bronchial asthma lack consistency, possibly because of ill defined diagnostic criteria, non-standardized study protocols, different methodologies, environmental exposures and the health care infrastructure ${ }^{8-10}$. A positive association was seen between asthma and increasing age in rural and urban areas. The present study shows more number of people within the age group 31-50 in the rural and urban areas. This finding is similar to the result obtained by Kaur et $\mathrm{al}^{12}$ and Rao et $\mathrm{al}^{13}$. A gender difference was noticed in this study with males being affected more than the females ${ }^{12}$. The male predominance may be related to a greater degree of bronchial labiality in males. This finding correlates with the finding of Jain et $\mathrm{al}^{14}$ and Rao et $\mathrm{al}^{13}$. However, according to Kaur et $\mathrm{al}^{12}$ and Mansi et $\mathrm{al}^{14}$ female predominance was found which was attributed to the fact that use of cow-dung cakes as fuel for cooking lead to airway inflammation and asthma ${ }^{12-15}$. The $3 / 4$ th of the total subjects in the present study resided in urban areas. In fact, urban subjects are more exposed to various environmental allergens and pollutants. This result is similar to the study of Kaur et $\mathrm{al}^{12}$. A positive association was seen between asthma and lower socioeconomic status people unlike the studies of Jain et $\mathrm{al}^{14}$ and Prasad et $\mathrm{al}^{16}$. This study is closely associated with the studies of Rao et $\mathrm{al}^{13}$ and Kaur et $\mathrm{al}^{12}$. The findings of the present study are concurrent with the well documented strong association of family history with the prevalence of asthma as seen in the studies of Prasad et $\mathrm{al}^{16}$, Kaur et $\mathrm{al}^{12}$ and Jain et $\mathrm{al}^{14}$.

The study of Jain et $\mathrm{al}^{14}$ shows strong association between family history of atopic disorder and the prevalence of asthma whereas the present study shows only $6 \%$ of atopic disorder among asthmatics ${ }^{14}$. This may be attributed to the geographical variation or sample size taken. Smoking emerged as a significant risk factor for asthma. Most of the studies show correlation with this factor. Our study shows only $40 \%$ of Asthmatic people were smokers. According to Jindal and Gupta ${ }^{3}$, smoking as a risk factor of asthma has remained debatable. In this study $28 \%$ of asthmatics had diabetes which does not show correlation with other studies. According to Dhar et $\mathrm{al}^{17}$, Vanufford ${ }^{18}$ and Abrahamson ${ }^{19}$ it was shown that attacks of asthma could be prevented by intake of glucose. According to Gluck and Rogala ${ }^{20}$ a confirmatory finding was reported and stated that asthma and diabetes rarely coexisted. Higher percentage of diabetics (24\%) was seen in the study of Mansi et $\mathrm{al}^{15}$ The present study shows that the higher percentage of diabetics $(28 \%)$ could be due to higher age group.

\section{Conclusion}

The data indicates that urban people, labour, literates and illiterates, people with low income are more affected because of their financial status. The increased number of asthmatics is mainly due to the environmental pollution. The study shows that it is essential to expand health care services and screening program for the diagnosis and treatment of asthma. 


\section{References}

1. Rai SP, Patil AP, Vardhan V, Marwah V, Pethe M, Pandey IM. Best treatment guidelines for bronchial asthma. Medical Journal Armed Forces India. 2007;63(3):264-8

2. Alderson M. Trends in morbidity and mortality from asthma. Population Trends. 1987(49):18-23

3. Jindal SK, Gupta D, Aggarwal AN, Agarwal R, World Health O. Guidelines for management of asthma at primary and secondary levels of health care in India (2005). The Indian journal of chest diseases \& allied sciences. 2005;47(4):309

4. Bracken MB, Belanger K, Cookson WO, Triche E, Christiani DC, Leaderer BP. Genetic and perinatal risk factors for asthma onset and severity: a review and theoretical analysis. Epidemiologic reviews. 2002;24(2):176-89.

5. Finkelstein JA, Barton MB, Donahue JG, Algatt-Bergstrom P, Markson LE, Platt R. Comparing asthma care for Medicaid and non-Medicaid children in a health maintenance organization. Archives of pediatrics \& adolescent medicine. 2000;154(6):563-8

6. Anuradha A, Lakshimi Kalpana V, Narasingarao S. Epidemilogical Study on Bronchial Asthma. Indian J Allergy Asthma Immunol 2011;3(12):434-6.

7. Asthma Association of Bangladesh. National guidelines Asthma \& COPD, 2012;1-55

8. Aggarwal AN, Chaudhry K, Chhabra SK, D Souza GA, Gupta D, Jindal

SK, et al. Prevalence and risk factors for bronchial asthma in Indian adults: a multicentre study. Indian Journal of Chest Diseases and Allied Sciences. 2006;48(1):13-22

9. Clark NM, Brown R, Joseph CLM, Anderson EW, Liu M, Valerio M, et al. Issues in identifying asthma and estimating prevalence in an urban school population. Journal of clinical epidemiology. 2002;55(9):870-81
10. Fergusson DM, Crane J, Beasley R, Horwood LJ. Perinatal factors and atopic disease in childhood. Clinical \& Experimental Allergy. 1997;27(12):1394-401

11. Zamel N, McClean PA, Sandell PR, Siminovitch KA, Slutsky AS. Asthma on Tristan da Cunha: looking for the genetic link. The University of Toronto Genetics of Asthma Research Group. American journal of respiratory and critical care medicine. 1996;153(6):1902-6

12. Kaur S, Behera D, Gupta D, Verma SK. Demographic and Environmental factors in patients of bronchial asthma. Indian J Allergy Asthma Immunol. 2008;22(2):85-9

13. Rao S, Ashok NC, Jain T, Anuradha R. Muralidhar, Influence of Associated Factors in the Prevalence of Asthma: A Community Based Study in Mysore. J Clin Diag Res 2011;5:721-4

14. Jain A, Bhat HV, Acharya D. Prevalence of bronchial asthma in rural Indian children: a cross sectional study from South India. The Indian Journal of Pediatrics 2010;77(1):31-5

15. Mansi R, Joshi SV, Pandloskar SR, Dhar HL. Correlation Between Blood Sugar, Cholesterol and Asthma Status. Indian J Allergy Asthma Immunol 2007;21(1):31-4.

16. Prasad R, Verma SK, Ojha S, Srivastava VK. A Questionnaire Based Study of Bronchial Asthma in Rural Children of Lucknow. Indian J Allergy Asthma Immunol. 2007;21:15-8

17. Dhar H.L Effect of varying blood sugar level in anaphylactic shock. Adv Exp Med Biol 1970; 8: 189-92

18. Vanufford NJQ. The blood Sugar level in Asthma .Int Arch Aller Appl Immunol 1952; 3:23

19. Abrahamson EH. Asthma diabetes mellitus and hyperinsulinemia. J Clin End Meta.1941; 1: 402

20. Gluck J, Rogala B. Coexistence of bronchial asthma and diabetes mellitus type 2-retrospective analysis. Pol Arch Med Wewn 1999; 101: 39-43 